\section{AUTHORS:}

Sumaiya Arabi $^{1}$

Anton Nahman²

\section{AFFILIATIONS:}

Smart Places, Council for Scientific and Industrial Research (CSIR),

Durban, South Africa

${ }^{2}$ Smart Places, Council for Scientific and Industrial Research (CSIR),

Stellenbosch, South Africa

\section{CORRESPONDENCE TO:}

Anton Nahman

EMAIL:

anahman@csir.co.za

\section{DATES:}

Received: 03 Dec. 2019

Revised: 25 Feb. 2020

Accepted: 18 Mar. 2020

Published: 27 May 2020

HOW TO CITE:

Arabi S, Nahman A. Impacts of marine plastic on ecosystem services and economy: State of South African research. S Afr J Sci. 2020;116(5/6), Art. \#7695, 7 pages. https://doi. org/10.17159/sajs.2020/7695

\section{ARTICLE INCLUDES: \\ 冈 Peer review}

$\square$ Supplementary material

DATA AVAILABILITY:

$\square$ Open data set

$\square$ All data included

$\square$ On request from author(s)

$\square$ Not available

囚 Not applicable

EDITORS:

Jane Carruthers iD

Linda Godfrey iD

KEYWORDS:

marine plastic debris, plastic pollution, economic impacts

\section{FUNDING:}

Waste RDI Roadmap, Council for Scientific and Industrial Research, Department of Science and Innovation (South Africa); Commonwealth Litter Programme, Centre for Environment, Fisheries and Aquaculture Science, Department for Environment, Food and Rural Affairs (UK)

\title{
Impacts of marine plastic on ecosystem services and economy: State of South African research
}

\begin{abstract}
In addition to its direct impacts on marine ecology and biota, marine plastic debris can affect the delivery of ecosystem services, with resulting impacts on human well-being, society and the economy. It is important to quantify these impacts in economic terms, so as to be able to provide evidence-based support for an appropriate policy response. We review the South African literature on the impacts of marine plastic debris on ecosystem services and on the economy, in order to identify relevant knowledge gaps. The gaps are found to be significant. Some research has been conducted in terms of impacts relating to recreation, aesthetics and tourism and the costs of beach and harbour clean-ups. However, there is a significant lack of research regarding impacts on ecosystem services relating to fisheries and aquaculture, heritage, habitat provision, biodiversity, and nutrient cycles. There is also a significant lack of research regarding direct economic impacts on the transport/shipping and fisheries industries, indirect economic impacts (such as costs associated with health-related impacts), and non-market costs (e.g. impacts on scenic, cultural and spiritual values). More research is needed in South Africa to address these gaps, in order to inform policy aimed at addressing plastic waste and marine plastic debris.

\section{Significance:}

- This review highlights the knowledge gaps in terms of the impacts of marine plastics on ecosystem services and on the economy in South Africa, which are important to understand in order to be able to direct funding for future research in this domain. Without better knowledge of the economic impacts of marine plastic debris, it is difficult to assess the costs of inaction, and therefore to inform an appropriate policy response for tackling the problem of marine plastic debris.
\end{abstract}

\section{Introduction}

Globally, the impacts of plastic debris on the marine environment have received increasing attention over the past decade. Jambeck et al. ${ }^{1}$ estimated that between 4.8 and 12.7 million metric tons of plastic waste entered the ocean from land-based sources in 2010, and that flows of plastic waste to the marine environment are likely to increase significantly in the absence of improved management. In Africa, the estimated total mismanaged waste in 2010 was 4.4 million metric tons, which is projected to increase to 10.5 million metric tons by 2025 if no significant changes are implemented. ${ }^{2}$

In South Africa, plastic recycling rates are relatively high (46.3\% in 2018), exceeding the average for Europe ${ }^{3}$ with $70 \%$ of the recycled tonnages coming from landfill and other post-consumer sources. Plastics recycling provided 7892 formal jobs in $2018^{3}$, as well as livelihoods for 58470 informal waste pickers and smaller entrepreneurial collectors ${ }^{3}$. The procurement of plastic recyclables in 2018 contributed ZAR2.3 billion to the South African economy at primary sourcing level. ${ }^{3}$

However, generally speaking, the state of waste management in South Africa is poor, with significant leakage of plastic debris to the environment, largely as a result of inadequate waste collection and disposal. Although Jambeck et al.' $\mathrm{s}^{1}$ oft-cited figures (suggesting that South Africa ranks 11th in the world in regard to the amount of plastic waste leaking into the ocean) are subject to debate ${ }^{4}$, there is evidence of an upward trend in marine plastic debris from land-based sources in South Africa ${ }^{5}$. For example, plastic items make up a higher proportion of macro-debris found on South African beaches in more recent studies as compared to older studies. ${ }^{5}$

Naidoo et al. ${ }^{6}$ provide an overview of the impacts of plastic debris on marine ecology and biota. In addition, however, to the extent that marine plastic debris can affect the structure and functioning of ecosystems more broadly, the increasing volume of plastics in the ocean could potentially have negative impacts on the delivery of marine ecosystem services, and in turn, on human well-being, society and the economy.

Ecosystem services refer to the valuable goods and services provided by ecosystems to human societies. While classification systems vary, they are generally understood as including supporting services (such as habitat provision and biodiversity), provisioning services (such as food, water and other resources), regulating services (such as climate regulation and nutrient cycles), and cultural services (such as recreation and education). ${ }^{7}$ The provision of such services to humankind is vital to human livelihoods and to sustained economic activity, and therefore has an intrinsic (although typically unaccounted for) economic value. ${ }^{7}$

However, the by-products of human activities, such as pollution and waste, can have a negative impact on ecosystem structure and functioning, and therefore on the continued ability of ecosystems to provide these services. ${ }^{7}$ In turn, this can have a negative impact on the economic value derived from such services. For example, to the extent that marine plastic debris has a negative impact on marine habitats and biodiversity, fishing stocks for commercial and recreational fishers may be negatively affected, which in turn has a negative economic impact. These negative impacts are referred to as externalities, that is, the side-effects of human activities which are not internalised in market prices. To the extent that these impacts are not quantified in economic terms, the benefits of a policy response (in terms of avoided damages) are difficult for policymakers to assess. It is therefore vital to be able to quantify the
(C) 2020. The Author(s). Published under a Creative Commons Attribution Licence. 
impacts of marine plastic debris on the economy, so as to be able to provide evidence-based support for an appropriate policy response.

We review the South African literature on the impacts of marine plastic debris on ecosystem services and on the economy, in order to be able to identify gaps. Research on ecological impacts is specifically excluded; for a review of this research, see Naidoo et al. ${ }^{6}$ in this issue. The following section provides a brief overview of the typical impacts of marine plastic debris on ecosystem services and on the economy as identified in international literature. The intention is to provide a framework against which to assess the current state of South African literature on each of these impacts, in order to identify gaps.

\section{Ecosystem service and economic impacts of marine plastic debris identified in international literature}

\section{Impacts on ecosystem services}

According to the Millennium Ecosystem Assessment $(\mathrm{MA})^{7}$ and The Economics of Ecosystems and Biodiversity (TEEB) ${ }^{8}$ frameworks, ecosystem services can be classified into four categories: supporting services, provisioning services, regulating services, and cultural services. While some classification systems (such as the Common International Classification of Ecosystem Services, CICES) ${ }^{9}$ differ slightly, for the purposes of this paper, the MA and TEEB systems provide a useful framework for structuring the discussion.

The main impacts of marine plastics on ecosystem services relate to provisioning services (fisheries and aquaculture), cultural services (recreation, aesthetics and heritage), and supporting services (e.g. impacts on habitat provision and biodiversity). ${ }^{10,11}$ There are also some suggestions of potential impacts on regulating services (e.g. nutrient cycles). ${ }^{10}$ In this section, we briefly review the typical expected impacts of marine plastic debris on each of these categories of ecosystem services.

\section{Impacts on provisioning services: Fisheries and aquaculture}

Seafood is an important food and protein source, making up $20 \%$ of the food intake (by weight) of 1.4 billion people worldwide. ${ }^{11}$ Naidoo et al. ${ }^{6}$ provide an overview of the impacts of marine plastic debris on individual organisms, through ingestion, entanglement, etc. Although there is currently a lack of knowledge regarding the resulting impacts on populations, to the extent that fish stocks could be impacted by marine plastic debris, the efficiency of commercial fisheries and aquaculture farms could potentially be negatively affected.

Ingestion can take place directly from the marine environment, or through the food chain. ${ }^{11-13}$ Studies have shown uptake of microplastics by mussels, which are filter-feeding organisms. Mussels are not only ecologically important, they are also important for subsistence and commercial harvesting. ${ }^{14}$ Impacts of exposure via the food chain can be detrimental due to possible accumulation and bio-magnification of microbial pathogens and toxic persistent organic pollutants in higher predators, although there is a lack of conclusive evidence in current research. ${ }^{15}$ The impacts of marine plastic debris on ecosystems - together with the cumulative impacts of climate change, ocean acidification and over-exploitation of marine resources - could potentially put the fishing and aquaculture industries at risk. ${ }^{15}$

Finally, there is potential for marine plastics to affect human health when entire contaminated organisms are ingested. This is further impacted by the accumulation of synthetic microfibres, toxic chemicals and persistent organic pollutants in shellfish and fish tissue, which have the potential to cause birth defects, cancer, and compromised immune systems, although there is currently a lack of scientific evidence regarding these health-related impacts. ${ }^{11,12}$ While some studies suggest that the risks for human health due to ingestion of plastic in contaminated species are minimal ${ }^{11,12}$, the high dependency on seafood by a large part of the world's population suggests that further research is required to clarify the extent of these risks ${ }^{11}$.

\section{Impacts on cultural services: Recreation, aesthetics and heritage}

In many parts of the world, visitors to coastal areas are frequently exposed to plastic debris. ${ }^{11}$ The presence of plastic debris has been found to be a key reason for visitors to the coastline to shorten their visits to a particular beach and sometimes even avoid a specific area. ${ }^{11}$ Furthermore, the presence of debris can impact both physical and mental health. Visitors and workers on the coastline can incur physical injuries such as cuts due to sharp debris, entanglement in nets, as well as exposure to unsanitary items. ${ }^{11}$ Exposure to polluted coastlines has also been shown to have a negative impact on individual's mental wellbeing and mood. ${ }^{11}$ Visiting beaches has important health benefits, such as promoting physical activity and social interactions, thereby improving physical and mental well-being. ${ }^{11}$ As such, in attempting to avoid the risks associated with polluted coastlines by not visiting beaches, health and well-being is likely to be negatively impacted. ${ }^{11}$ In addition, marine debris can negatively affect peoples' quality of life by reducing the aesthetic appeal of the marine environment. ${ }^{15}$

The presence of marine plastics can also have negative impacts on the heritage of communities and individuals. People tend to have an emotional and/or cultural attachment to marine organisms such as turtles, seabirds and cetaceans. According to Beaumont et al. ${ }^{11}$, the expectation that these marine organisms exist and will continue to exist in future has an impact on the well-being of humans, irrespective of whether they ever get to see or interact with these animals. The potential loss of these animals (e.g. through ingestion, entanglement, or reduced reproductive success), which has gained significant public attention in recent years, could therefore have a negative impact on the well-being of humans. ${ }^{11}$

\section{Impacts on supporting services: Habitat provision, biodiversity and invasive species transport}

According to Mouat et al. ${ }^{15}$, approximately $70 \%$ of marine debris accumulates on the ocean floor, where it can significantly impact benthic organisms and habitats. In particular, such debris can prevent gas exchanges and reduce the amount of oxygen in sediments, which impacts negatively on ecosystem functioning, benthic organisms and the composition of biota on the ocean floor. It can also physically damage benthic habitats through abrasion, scouring, and breaking; while derelict fishing gear has the potential to translocate organisms and seabed features. ${ }^{15}$

In addition, marine plastic debris has the potential to significantly impact marine ecology and biodiversity, which could in turn severely impact the resilience of such ecosystems in the face of global change. ${ }^{11}$ However, there is currently a lack of understanding regarding the extent to which impacts associated with ingestion, entanglement, damage to benthic environments and loss of biodiversity will interact to cause deterioration of marine ecosystems in the long term. ${ }^{15}$

Finally, marine plastic provides a habitat on which invasive species can become attached and be transported over long distances (see also Naidoo et al. ${ }^{6}$ ). Floating plastics allow for the attachment and transport of alien species and disease, thereby potentially modifying pelagic ecosystems. ${ }^{11,13,16,17}$ Plastic, unlike natural flotsam, is able to withstand UV exposure and wave action, and is able to remain buoyant for extended periods, thereby travelling great distances with the colonised species attached. ${ }^{11}$ For example, a study along the Catalan coast showed primarily benthic diatoms and small flagellates $(<20 \mu \mathrm{m})$ attached to plastic debris. Potentially harmful dinoflagellates, resting cysts of unidentified dinoflagellates and both temporary cysts and vegetative cells of the harmful algal bloom species, Alexandrium taylori, were also found. ${ }^{18}$

\section{Impacts on regulating services: Nutrient cycles}

While there is less information regarding the impacts of marine plastic debris on regulating services compared with the other categories of ecosystem services, there are some suggestions of a potential impact on nutrient cycles. For example, plastic could affect the buoyancy of faecal matter discharged from marine outfalls, thereby affecting the movement of nutrients and carbon into the deep ocean, potentially disrupting nutrient 
cycles, ${ }^{10}$ although the small volumes involved relative to global nutrient and carbon cycles implies that this impact is likely to be negligible.

\section{Economic impacts}

In 2011, marine ecosystem services were estimated to contribute USD49.7 trillion per year in terms of benefits to global society. ${ }^{11}$ These values were calculated based on actual or hypothetical maximum sustainable use of natural or semi-natural systems with minimal anthropogenic impacts. Although there are limitations to the accuracy of the method, the figure above has been acknowledged for its use in global analysis and to determine the decline in value of marine ecosystem services due to the impacts of marine plastics. This figure can therefore be used as a baseline to provide an order of magnitude estimate of the costs of marine plastic debris, in terms of various levels of decline in ecosystem service delivery. ${ }^{11}$ While it is difficult to accurately quantify the loss of ecosystem services due to marine plastic debris, Beaumont et al. ${ }^{11}$ estimated a $1-5 \%$ decline in ecosystem services as a result of marine plastics in 2011. Based on the value of marine services to society of USD49.7 trillion per year, this equates to a loss of USD0.5-2.5 trillion in the value of benefits derived from marine ecosystem services annually, as a result of marine plastic debris. Based on a 2011 estimate of 75-150 million tonnes of plastic in the marine environment, the annual cost in terms of reduced marine natural capital is between USD3300 and USD33 000 per tonne of plastic. It is important to note that this calculated cost covers only the impact on marine natural capital, and is therefore lower than the full economic cost of marine plastic debris. ${ }^{11}$

Mouat et al..$^{15}$ identified a number of specific economic impacts associated with marine debris, including cleaning costs; losses to tourism; losses to fisheries; losses to aquaculture; costs to shipping; costs of control and eradication of invasive non-native species; costs to coastal agriculture; costs to power stations; and costs of environmental damage and ecosystem degradation. These impacts are also for the most part discussed in Mcllgorm et al. ${ }^{19}$ who distinguish three broad categories of costs resulting from marine debris:

1. direct economic costs, arising from damage to an industry or economic activity, e.g. impacts on the fishing, transportation/shipping and tourism industries (relatively straightforward to quantify);

2. indirect economic costs, e.g. the impacts on human health resulting from marine life ingesting plastic and contaminating the food chain (more difficult to quantify); and

3. 'non-market' costs, which impact the value that humans place on the marine environment over and above the value associated with the actual use of marine resources, such as scenic value, cultural value, and spiritual value (most difficult to quantify).

These categories are briefly discussed in turn below.

\section{Direct economic costs}

Mcllgorm et al. ${ }^{19}$ estimated the direct economic costs of marine debris on the Asia-Pacific Economic Cooperation region. They found that the main impacts were on the fishing industry (USD364 million in 2008), transportation/shipping (USD279 million), and the tourism industry (USD622 million), with a combined impact of USD1.265 billion in 2008. ${ }^{19}$

These results suggest that the main economic impact of marine plastics is on tourism revenue. This is particularly significant in areas that rely heavily on tourism. For example, researchers in Florida (USA) have found that debris is considered undesirable for a popular tourist destination, and highlighted the importance to Florida's economy of ensuring that an attractive environment is maintained. ${ }^{20} \mathrm{~A}$ study of marine debris on the US East Coast in 1987-1988 estimated a loss of between USD379 and USD1 598 million. ${ }^{21}$ In South Korea, a heavy rainfall event which increased coastal waste resulted in a $63 \%$ drop in tourism, and an associated loss in revenue of USD33 million. ${ }^{21}$

Leggett et al. ${ }^{22}$ found that marine debris impacted on residents of Orange County in California (USA) in terms of additional costs spent to avoid degraded areas. Residents were willing to travel to clean beaches even it if meant more time and money being spent, costing locals millions of dollars per year. It was found that a $50 \%$ reduction in marine debris would save residents USD67 million in total over a period of 3 months.

In order to avoid losses in terms of tourism revenue, some municipalities incur high costs for clean-up operations to remove debris from beaches and public use areas. ${ }^{21}$ For example, municipalities in Belgium, the Netherlands and the UK spend between EUR10-20 million (USD10.721.5 million) per year to clean up debris affecting coastal tourism..$^{21,23}$ Funding requirements for clean-ups and implementation of litter prevention strategies increased in the archipelago of Svalbard from NOK20 million in 2016 to NOK280 million in 2018 (USD2.15-30.1 million). ${ }^{24}$

Marine plastic debris can negatively impact the shipping industry, e.g. due to fouling of propellers, damage to drive shafts, fouled anchors, clogging of intake pipes, and increasing maintenance and repair costs. ${ }^{19,23,25}$ Mcllgorm et al. ${ }^{19}$ found that marine debris causes approximately USD19 000 worth of damage per vessel per year to Hong Kong's high-speed ferry network. Like the clean-up operations undertaken by municipalities to reduce tourism-related impacts, some harbours incur clean-up costs to reduce impacts on the shipping industry. For example, harbours in the UK spend approximately EUR2.4 million (USD2.6 million) annually on marine waste removal. ${ }^{23}$ Werner et al. ${ }^{23}$ reported that the Spanish Port of Barcelona carries out daily clean-ups of floating debris, collecting over 117 tonnes in 2012 at a cost of approximately EUR300 000 (USD330 000).

In addition, marine plastic debris has negative impacts on the fishing industry. For example, marine debris has been found to result in restricted catch due to litter in nets for $86 \%$ of Scottish fishing vessels, costing these fleets on average EUR11.7-13 million (USD12.8-14.2 million) per year. This equates to approximately $5 \%$ of the total revenue of affected fisheries. ${ }^{26}$

Finally, both the shipping and fisheries industries can be affected by derelict fishing gear through damage to vessels (e.g. fouled propellers), the costs of replacing lost gear, as well as the potential loss of catch (reduced fishing time and contaminated catch), resulting in reduced revenue. ${ }^{15}$ In 2002, losses of approximately USD21 000 in fishing gear and USD38 000 in fishing time were experienced by a single trap fisher in the Scottish Clyde fishery. ${ }^{15}$ An estimated USD250 million worth of marketable lobster is lost to 'ghost' fishing annually in the USA, and between 4-10 million blue crabs are trapped in ghost fishing gear annually in Louisiana, USA. ${ }^{15}$

\section{Indirect and non-market economic costs}

Indirect costs associated with marine plastic debris include human health and safety costs (from consumption of contaminated species, navigational hazards, injuries to recreational users, leaching of poisonous chemicals, etc.) ${ }^{15}$ Current literature does not provide clarity on the health risks associated with marine plastic ${ }^{11,12,27}$, although some research suggests that it is minimal11. It is therefore difficult to quantify the associated economic impacts.

Non-market costs associated with marine plastic debris, such as impacts on scenic value, heritage value, and spiritual value, have not been assessed in any great depth, based on our brief review of the international literature.

\section{Status quo: South African research on ecosystem service and economic impacts of marine plastic debris}

In this section, we review the South African research that has been undertaken in assessing the impacts of marine plastic debris on ecosystem services and on the economy, under each of the categories identified above, in order to identify gaps. A comprehensive review was undertaken using a wide range of databases (Scopus, ScienceDirect, Taylor and Francis, SpringerLink, and Google Scholar) and various combinations of all relevant keywords, as identified based on the framework established from the international review. The keywords were: economic, marine litter, South Africa, socio-economic, human health, agriculture, fisheries, commercial fisheries, recreational fishing, aquaculture, harbours, ports, shipping, marine plastic litter, marine plastic debris, ecosystem service, ecosystem service impact, plastic, ecosystem services, Africa, food contamination, pollutant accumulation, litter, nutrient 
cycles, marine debris, pollution, plastic pollution, marine plastic pollution, economic cost, economic impact, coastal communities, livelihoods, food security, microplastics, human health, human safety, recreation impacts, cultural impacts, shipping hazards, ghost gear, subsistence fishing, beach clean-ups, beach aesthetics, beach cleanliness, biodiversity, habitats destruction, invasive species, species transport, tourism costs, and port clean-up costs. We also consulted with a number of South African experts to identify any other relevant literature that had been missed.

\section{Impacts on ecosystem services}

Very little research could be found that specifically assessed the impacts of marine plastic debris on ecosystem services in South Africa. The following sub-sections provide an overview of South African research on each of the specific categories of ecosystem services identified in the previous section.

\section{Impacts on provisioning services: Fisheries and aquaculture}

Over 12 million people engage in the fisheries sector in Africa. In addition, subsistence fishing in Africa is practised by multiple communities, and plastic pollution could potentially have a significant impact on their livelihoods and food security. ${ }^{2}$ However, no research could be found specifically assessing the impacts of marine plastic debris on fisheries and aquaculture in South Africa.

\section{Impacts on cultural services: Recreation, aesthetics and heritage}

There has been some research in South Africa on the impacts of marine debris on tourism, which includes aspects related to recreation and aesthetics. All of this research is focused on identifying the economic impacts on the tourism industry, or the costs of beach clean-ups to mitigate such impacts. As such, this research is discussed in the section below on economic impacts. No research could be found regarding impacts on ecosystem services associated with heritage.

\section{Impacts on supporting services: Habitat provision, biodiversity and invasive species transport}

While a fair amount of research has been conducted on the impacts of plastic pollution on marine biota in South Africa (see Naidoo et al. ${ }^{6}$ ), much less literature is available on supporting ecosystem services such as habitat provision and biodiversity.

A number of studies have, however, examined the issue of marine plastics acting as a substrate for the attachment and transport of species, although not for invasive alien species specifically. Whitehead et al. ${ }^{28}$ sampled 22 beaches in South Africa for debris that had been colonised by goose barnacles (Lepas spp). It was found that plastic was one of the two most colonised substrate types, at $29 \%$ of all colonised items; second only to kelp at 33\% (although given that significantly more kelp is stranded on beaches than plastic, plastic appears to have a higher likelihood of being colonised). All species identified were found to colonise plastic debris, thereby impacting the abundance and distribution of goose barnacles, where large, natural substrata are not commonly available. ${ }^{28}$ Similarly, Fazey and Ryan ${ }^{17}$ found a range of epibionts on marine plastic debris, including red and green algae, bryozoans, barnacles, polychaetes and mussels.

Although the above studies found evidence of the attachment and transport of species on plastic, there is little evidence of plastic serving as a substrate for alien species entering South African waters. Robinson et al. ${ }^{29}$ found that the main vectors of transport for these species included attachment to shipping vessels, via ballast water and through mariculture operations. Marine plastic debris was not identified as a possible vector of invasive species transport in their 2005 review, although it would be interesting to see whether this may have changed more recently.

\section{Impacts on regulating services: Nutrient cycles}

No South African research was found relating to the impacts of marine plastic debris on regulating services, such as nutrient cycles.

\section{Economic impacts}

\section{Direct economic costs}

As a popular tourist destination, South Africa's tourism industry is a significant contributor to the economy, employing 1.5 million workers (9.8\% of total employment) and contributing ZAR125 billion (USD8.2 billion) directly to GDP in 2016 (2.9\% of GDP), or ZAR422.6 billion (USD27.7 billion) including indirect and induced effects (9.2\% of GDP). ${ }^{30}$ Marine ecotourism specifically contributed approximately ZAR400 million (USD26 million) directly, and over ZAR2 billion (USD130 million) indirectly, to the South African economy in 2014. ${ }^{31}$ In Cape Town, for example, visiting the beach makes up $12 \%$ of foreign visitors' activities in the city. ${ }^{31}$

There has been some research in South Africa on the impacts of marine debris on tourism. To the extent that marine debris impacts on the aesthetic value of the coast, and decreases the number of visitors to polluted beaches, increasing quantities of marine plastic debris can be expected to negatively affect the tourism industry, and therefore the economy. ${ }^{32-34}$ Ballance et al. ${ }^{32}$ found that cleanliness was the primary factor influencing visitors to the Cape Peninsula when choosing a beach, particularly for international tourists. Almost $50 \%$ of residents would be prepared to spend more to visit clean beaches further away; while litter densities of more than 10 large items per metre of beach would deter $40 \%$ of foreign tourists, and $60 \%$ of domestic tourists, from returning to Cape Town, with a significant potential impact on the local economy. ${ }^{32}$ If beaches had more than 10 large debris items per metre, $97 \%$ of visitors would not visit them, leading to a decline in total recreational value of approximately ZAR300 000 (USD19 600) per year, and a loss of ZAR8 million (USD520 000) for the regional economy (based on 1996 values; equivalent to approximately ZAR1 million and ZAR27 million, respectively, in current values). ${ }^{32}$

A number of studies have also assessed the costs of beach clean-ups aimed at mitigating negative impacts on the tourism industry, although most were undertaken in the mid-1990s. According to Swanepoel ${ }^{35}$, the Cape Town City Council spent ZAR2.7 million (USD176 000) on beach clean-ups in 1992-1993; equivalent to approximately ZAR12 million in current values. Compared to the domestic refuse removal cost of approximately ZAR75 (USD4.9) per tonne, the cost for removal of beach debris amounted to ZAR3000 (USD190) per tonne. ${ }^{35}$ According to Ballance et al. ${ }^{32}$, given the large amount of expenditure on beach cleaning in Cape Town (ZAR3 million / USD196 000 during 1994-1995), alternative means of reducing debris at source are required.

Ryan and Swanepoel ${ }^{34}$ carried out a study in 1994-1995 of 63 coastal authorities in South Africa to assess the amount of effort spent on cleaning beaches. A total of 34 authorities estimated their annual costs for beach cleaning to be ZAR5.5 million (USD360 000), with the Cape Town metropolitan region alone spending in excess of R3.5 million (USD229 000) annually. Costs varied depending on the location of the beaches, with west coast beaches (ZAR397/ $/ \mathrm{km})$ costing more than those on the east coast (ZAR68/km) due to larger volumes of kelp. When the data were extrapolated for areas that did not provide estimates, the total cost for cleaning in 1994-1995 across the 63 authorities exceeded ZAR8 million (USD520 0000) - equivalent to approximately ZAR31 million in current terms. ${ }^{34}$

Finally, one of the projects under the South African Department of Environment, Forestry and Fisheries' national Working for the Coast programme involves beach clean-ups, although the costs of such cleanups could not be found in published sources.

In terms of damage to the shipping industry, debris (including plastic) in and around the Port of Durban can become a shipping hazard, particularly after periods of rainfall. However, there has been little assessment of the associated economic impacts. The Port incurs costs in debris clearing operations, while there are also public volunteer clean-ups of plastic from the Port. There are also public clean-ups of estuaries and beaches in eThekwini, although the costs of these operations have not been quantified in published sources. Based on information received from the Port through personal communication, clean up-costs due to storm events in April/May 2019 ranged between ZAR52 800 (USD3400) and 
ZAR1 046000 (USD68 400), and totalled ZAR4 350000 (USD284 800) in that period alone (Transnet 2019, written communication, August 22).

There is a lack of research regarding the impacts of marine plastics on the fishing industry in South Africa. In 2012, the commercial fisheries sector produced ZAR5.8 billion (USD370 million) in output, while the estimated economic value of the recreational fishing sector in 2017 was ZAR1.6 billion (USD104 million). ${ }^{31}$ The aquaculture sector contributed approximately $0.8 \%$ to South Africa's fish production in $2012 .{ }^{31}$ However, there is a significant lack of information regarding the impacts of marine plastics on these sectors.

Finally, no South African research could be found regarding the impacts of ghost fishing gear on the shipping or fisheries industries.

\section{Indirect and non-market economic costs}

No South African research could be found on indirect costs associated with marine plastic debris, e.g. costs associated with impacts on human health and safety; or on non-market costs, such as impacts on scenic value, cultural value, or spiritual value.

\section{Current uncertainties}

Globally, there is generally a lack of evidence regarding the overall effects of marine plastics on populations of marine species, or on ecosystem structure and functioning, and, therefore, on the provision of ecosystem services, as well as on human health, society and the economy. There are some studies that provide insight into the impacts of plastics on ecosystem services and the economy at a local level, but it is difficult to extrapolate these results more widely. In the South African context, for example, most studies focus on the impacts on tourism and the costs of beach clean-ups in the Cape Town area. There is a clear need to quantify the impacts of marine plastics on ecosystem services and on the South African economy more broadly.

Even in the international literature, there is a lack of evidence with regard to the impacts of marine plastics on ecosystem services, human health and on the economy, with much of the research seemingly focused instead on impacts on marine biota. Globally, it remains challenging to accurately quantify the loss of ecosystem services due to marine plastic debris. In addition, there are uncertainties around the long-term impacts of plastic pollution on marine ecosystems, that is, regarding how impacts such as ingestion, entanglement, damage to benthic environments and loss of biodiversity may interact and affect marine ecosystems over the long term. ${ }^{15}$

More research is also required to assess the risks of marine debris for human health and safety, e.g. in terms of the impact of consuming contaminated seafood, navigational hazards, injuries to recreational users, and the leaching of poisonous chemicals. ${ }^{15,16}$ In particular, there is a need for research into the effects of microplastic pollution on aquatic and marine ecosystems, and on human health. ${ }^{15,36,37}$ For example, there is a need to assess whether microplastic and microfibre pollution has ecosystem or human health implications such as chemical toxicity or fibre-induced mesothelioma, which would have negative impacts on both river biota and downstream communities as well as marine ecosystems. ${ }^{36,37}$

Finally, there is a need for more research to quantify the environmental and social impacts of marine plastic debris in economic terms, in order to provide an understanding of the costs of inaction. ${ }^{15}$ In particular, Beaumont et al. ${ }^{11}$ suggest that there is a need to quantify and assess a broader range of social and economic costs, e.g. direct and indirect impacts on the tourism, transport and fisheries sectors, as well as on human health. It is also important to take into account spatial and temporal heterogeneity and non-linearity with respect to the impact of each additional tonne of marine plastic debris entering the marine environment. ${ }^{11}$

\section{Evidence gaps}

From an economic and ecosystem services perspective, there is very little research that has been done in South Africa regarding the impacts of marine plastics, and therefore the gaps in local knowledge are significant. Table 1 provides a summary of the key impacts that have been identified in the international literature. The last column summarises the state of current South African research on each impact. Some research has been conducted regarding impacts on recreation, aesthetics and tourism, and the costs of beach and harbour clean-ups. However, there is a significant lack of research regarding impacts on ecosystem services relating to fisheries and aquaculture, heritage, habitat provision, biodiversity, and nutrient cycles. There is also a significant lack of research regarding direct economic impacts on the transport/shipping and fisheries industries, indirect economic impacts (such as costs associated with health-related impacts), and non-market costs (e.g. impacts on scenic, cultural and spiritual values). More research is required in South Africa to address these gaps, in order to be able to inform policy decisions.

\section{Implications}

Without better knowledge of the economic impacts of marine plastic debris, it is difficult to assess the costs of inaction, and therefore to inform an appropriate policy response. While it is potentially possible to apply the quantified estimates from other countries to South Africa in order to estimate orders of magnitude, those numbers should first be interrogated to ensure that this can be done with confidence, while the South African context needs to be taken into account in adapting these

Table 1: State of South African research on the impacts of marine plastic debris on ecosystem services and the economy

\begin{tabular}{|c|c|c|c|}
\hline Category & Sub-category & Impacts & South African research \\
\hline \multirow{7}{*}{$\begin{array}{l}\text { Impacts on ecosystem } \\
\text { services }\end{array}$} & Provisioning services & Impacts on fisheries and aquaculture & - \\
\hline & \multirow{2}{*}{ Cultural services } & Impacts on recreation and aesthetics & Some research on the impacts on tourism (see below) \\
\hline & & Impacts on heritage & - \\
\hline & \multirow[b]{3}{*}{ Supporting services } & Impacts on habitat provision & - \\
\hline & & Impacts on biodiversity & - \\
\hline & & Invasive species transport & $\begin{array}{c}\text { Some studies on plastic as a vector for transport } \\
\text { of species, }{ }^{13,14,26} \text { but not for invasive alien } \\
\text { species specifically }\end{array}$ \\
\hline & Regulating services & Nutrient cycles & - \\
\hline \multirow{5}{*}{ Economic impacts } & \multirow{3}{*}{ Direct costs } & Impacts on the tourism industry & $\begin{array}{c}\text { Some research conducted on the impacts on tourism } \\
\text { and on beach clean-up costs, although fairly dated } \\
\text { and largely confined to Cape Town }{ }^{32,34,35}\end{array}$ \\
\hline & & $\begin{array}{l}\text { Impacts on the transport/shipping } \\
\text { industry }\end{array}$ & $\begin{array}{l}\text { Information on harbour clean-up costs in Durban } \\
\text { obtained through personal communication; no } \\
\text { published information could be found }\end{array}$ \\
\hline & & Impacts on the fisheries industry & - \\
\hline & \multirow{2}{*}{ Indirect and non-market costs } & Health costs & - \\
\hline & & Non-market costs & - \\
\hline
\end{tabular}


figures. However, primary research conducted in South Africa should be considered preferable.

Finally, a more holistic understanding of the impacts of marine plastics is needed in order to change the way we make, use and reuse plastics, and therefore to reduce its negative impacts. This will also inform changes in behaviour by the public, legislative and governance changes, and changes to the plastic industry, towards the sustainable use, management and disposal of plastics ${ }^{11}$, and the development of a circular plastics economy.

\section{Acknowledgements}

We acknowledge the funding support for the preparation of this review paper from the South African Department of Science and Innovation (DSI), through the Waste RDI Roadmap, managed by the Council for Scientific and Industrial Research (CSIR). Subsidiary funding was provided under the umbrella of the Commonwealth Litter Programme (CLiP) implemented by the Centre for Environment, Fisheries and Aquaculture Science (Cefas), funded by the United Kingdom Government's Department for Environment, Food and Rural Affairs (Defra). Steven Weerts and Krishni Krishna (both CSIR), Peter Ryan (University of Cape Town), David Lerpiniere (Resource Futures) and Takunda Chitaka provided guidance in identifying key literature sources. Linda Godfrey (CSIR), Takunda Chitaka and Peter Ryan provided valuable comments on an earlier draft, and a number of individuals including Henry Roman (DSI), Reza Daniels (UCT) and Lara van Niekerk (CSIR) provided further comments following a presentation of the draft paper in October 2019. The two anonymous reviewers are also gratefully acknowledged.

\section{References}

1. JambeckJR, GeyerR, Wilcox C, Siegler TR, Perryman M, Andrady A, etal. Plastic waste inputs from land into the Ocean. Science. 2015;347(6223):768-771. https://doi.org/10.1126/science.1260352

2. JambeckJ, Hardesty BD, Brooks AL, Friend T, Teleki K, Fabres J, et al. Challenges and emerging solutions to the land-based plastic waste issue in Africa. Mar Policy. 2018;96:256-263. https://doi.org/10.1016/j.marpol.2017.10.041

3. Plastics SA. National Plastics Recycling Survey 2018 - Executive Summary 2019 [document on the Internet]. c2019 [cited 2020 Feb 25]. Available from: https://www.plasticsinfo.co.za/wp-content/uploads/2019/08/PlasticsRecycling-in-SA-July-2018-Executive-Summary-final.pdf

4. Ryan PG. The transport and fate of marine plastics in South Africa and adjacent oceans. S Afr J Sci. 2020;116(5/6), Art. \#7677, 9 pages. https:// doi.org/10.17159/sajs.2020/7677

5. Chitaka TY, Von Blottnitz H. Accumulation and characteristics of plastic debris along five beaches in Cape Town. Mar Pollut Bull. 2019;138:451-457. https:// doi.org/10.1016/j.marpolbul.2018.11.065

6. Naidoo T, Rajkaran A, Sershen. Impacts of plastic debris on biota and implications for human health: A South African perspective. S Afr J Sci. 2020;116(5/6), Art. \#7693, 8 pages. https://doi.org/10.17159/sajs.2020/7693

7. Millennium Ecosystem Assessment. Ecosystems and human well-being: Synthesis. Washington, DC: Island Press; 2005. Available from: https://www. millenniumassessment.org/documents/document.356.aspx.pdf

8. The Economics of Ecosystems and Biodiversity (TEEB). Mainstreaming the economics of nature: A synthesis of the approach, conclusions and recommendations of TEEB [webpage on the Internet]. c2010 [cited 2020 Feb 25]. Available from: http://www.teebweb.org/publication/mainstreamingthe-economics-of-nature-a-synthesis-of-the-approach-conclusions-andrecommendations-of-teeb/

9. Haines-Young R, Potschin M. Common International Classification of Ecosystem Services (CICES V5.1): A policy brief. One Ecosystem. 2018;3, e27108, 6 pages. https://doi.org/10.3897/oneeco.3.e27108

10. Mendenhall E. Oceans of plastic: A research agenda to propel policy development. Mar Policy. 2018;96:291-298. https://doi.org/10.1016/j. marpol.2018.05.005

11. Beaumont NJ, Aanesen M, Austen MC, Börger T, Clark JR, Cole M, et al. Global ecological, social and economic impacts of marine plastic. Mar Pollut Bull. 2019;142:189-195. https://doi.org/10.1016/.jmarpolbul.2019.03.022
12. Hamid FS, Bhatti MS, Anuar N, Anuar N, Mohan P, Periathamby A. Worldwide distribution and abundance of microplastic: How dire is the situation? Waste Manag Res. 2018;36:873-897. https://doi. org/10.1177\%2F0734242X18785730

13. Fazey FMC, Ryan PG. Debris size and buoyancy influence the dispersa distance of stranded litter. Mar Pollut Bull. 2016;110:371-377. http://dx.doi. org/10.1016/i.marpolbul.2016.06.039

14. Gerber G. More than just food: Mussels as biomonitors of microplastic pollution in the Kwazulu-Natal coastal environment [MSc thesis] Durban: UKZN; 2017. https://researchspace.ukzn.ac.za/bitstream/handle/10413/16224/Gerber Gemma_2017.pdf

15. Mouat J, Lozano R, Bateson H. Economic impacts of marine litter [document on the Internet]. c2010 [cited 2020 Feb 25]. Available from: http://www. kimointernational.org/wp/wp-content/uploads/2017/09/KIMO_EconomicImpacts-of-Marine-Litter.pdf

16. Almroth $\mathrm{BC}$, Eggert H. Marine plastic pollution: Sources, impacts, and policy issues. Rev Environ Econ Policy. 2019;13:317-326. https://doi.org/10.1093/ reep/rez012

17. Fazey FMC, Ryan PG. Biofouling on buoyant marine plastics: An experimental study into the effect of size on surface longevity. Environ Pollut. 2016;210:354360. http://dx.doi.org/10.1016/j.envpol.2016.01.026

18. Masó $\mathrm{M}$, Garcés E, Pagès F, Camp J. Drifting plastic debris as a potential vector for dispersing Harmful Algal Bloom (HAB) species. Sci Mar. 2003;67:107-111. https://doi.org/10.3989/scimar.2003.67n1107

19. Mcllgorm A, Campbell HF, Rule MJ. Understanding the economic benefits and costs of controlling marine debris in the APEC region. A report to the Asia-Pacific Economic Cooperation Marine Resource Conservation Working Group by the National Marine Science Centre (University of New England and Southern Cross University), Coffs Harbour, NSW; 2008.

20. Marais M, Armitage NPS. Proposed catchment management strategies to reduce litter loadings in South African urban drainage systems. Paper presented at: WISA 2000 Biennial Conference; 2000 May 28 - June 01; Sun City, South Africa.

21. Hardesty BD, Lawson T, Van der Velde T, Lansdell M, Wilcox C. Estimating quantities and sources of marine debris at a continental scale. Front Eco Environ. 2017;15:18-25. https://doi.org/10.1002/fee.1447

22. Leggett C, Scherer N, Curry M, Bailey R, Haab T. Assessing the economic benefits of reductions in marine debris: A pilot study of beach recreation in Orange County, California [document on the Internet]. c2014 [cited 2020 Feb 25]. Available from: https://marinedebris.noaa.gov/sites/default/files/ publications-files/MarineDebrisEconomicStudy_0.pdf

23. Werner S, Budziak A, Van J, Galgani F, Hanke G, Maes T, et al. JRC Technical Report: Harm caused by marine litter. MSFD GES TG Marine Litter - Thematic Report. Luxembourg: European Union; 2016. http://dx.doi. org/10.2788/690366

24. Abate TG, Börger T, Aanesen M, Falk-Andersson J, Wyles KJ, Beaumont $\mathrm{N}$. Valuation of marine plastic pollution in the European Arctic: Applying an integrated choice and latent variable model to contingent valuation. Ecol Econ 2020;169:1-10. https://doi.org/10.1016/j.ecolecon.2019.106521

25. Madzena A, Lasiak T. Spatial and temporal variations in beach litter on the Transkei coast of South Africa. Mar Pollut Bull. 1997;34(11):900-907. Available from: https://doi.org/10.1016/S0025-326X(97)00052-0

26. Oosterhuis F, Papyrakis E, Boteler B. Economic instruments and marine litter control. Ocean Coast Manag. 2014;102:47-54. http://dx.doi.org/10.1016/j. ocecoaman.2014.08.005

27. Keswani A, Oliver DM, Gutierrez T, Quilliam RS. Microbial hitchhikers on marine plastic debris: Human exposure risks at bathing waters and beach environments. Mar Environ Res. 2016;118:10-19. Available from: http://dx.doi. org/10.1016/..marenvres.2016.04.006

28. Whitehead TO, Biccard A, Griffiths CL. South African pelagic goose barnacles (Cirripedia, Thoracica): Substratum preferences and influence of plastic debris on abundance and distribution. Crustaceana. 2011:84:635-649. Available from: https://www.jstor.org/stable/23034314

29. Robinson T, Griffiths C, McQuaid C, Rius M. Marine alien species of South Africa - status and impacts. Afr J Mar Sci. 2005;27:297-306. https:// doi.org/10.2989/18142320509504088 
30. South African Department of Tourism. South Africa: State of tourism report, 2016/17. c2018 [cited 2019 Sep 03]. Available from: https://www.tourism. gov.za/AboutNDT/Publications/State\%20 of\%20Tourism\%20Report\%20 2016-17.pdf

31. WWF-SA. Oceans facts and futures: Valuing South Africa's ocean economy. Cape Town: WWF-SA; 2016.

32. Ballance A, Ryan P, Turpie J. How much is a clean beach worth? The impact of litter on beach users in the Cape Peninsula, South Africa. S Afr J Sci. 2000;96:210-213.

33. Ryan P. The marine plastic debris problem off southern Africa: Types of debris, their environmental effects, and control measures; 1990. In: Shomura RS Godfrey L, editors. Proceedings of the Second International Conference on Marine Debris; 1989 April 2-7; Honolulu, Hawaii. U.S. Dep. Commer., NOAA Technical Memo. NMFS, NOAA-TM-NMFS-SWFSC-154.
34. Ryan PG, Swanepoel D. Cleaning beaches: Sweeping the rubbish under the carpet. S Afr J Sci. 1996;92(June):275-276.

35. Swanepoel D. An analysis of beach debris accumulation in Table Bay Cape Town, South Africa [MSc thesis]. Cape Town: University of Cape Town 1995. https://open.uct.ac.za/bitstream/handle/11427/28474/Swanepoel_An_ Analysis_Beach_Debris_1995_1.pd

36. De Villiers S. Quantification of microfibre levels in South Africa's beach sediments, and evaluation of spatial and temporal variability from 2016 to 2017. Mar Pollut Bull. 2018;135:481-489. https://doi.org/10.1016/j. marpolbul.2018.07.058

37. De Villiers S. Short communication: Microfibre pollution hotspots in river sediments adjacent to South Africa's coastline. Water SA. 2019;45:97-102. https://doi.org/10.4314/wsa.v45i1.11 